\title{
Properties and in-service performance of components reated with thermo reactive deposition/diffusion
}

\author{
Propiedades y desempeño en servicio de componentes tratados \\ con deposición/difusión termorreactiva
}
D.M. Marulanda ${ }^{1 *}$
D. Toro $^{2}$
F.E. Castillejo ${ }^{3}$
B.A. Páez-Sierra ${ }^{1}$
J.J. Olaya ${ }^{4}$

Recibido 2 de septiembre de 2016, aceptado 25 de septiembre de 2017

Received: September 2, 2016 Accepted: September 25, 2017

\begin{abstract}
Machine components and tools subjected to aggressive environments and strong wear conditions need surfaces with good mechanical properties. The thermo-reactive deposition/diffusion (TRD) process is one of the methods used for improving the mechanical properties of these components and tools, mainly because of its low cost and good performance of the coatings deposited. Although the TRD process is widely used for coating dies, extrusion tools and punches among others, the in-service performance of cutting tools coated using the TRD process has not been extensively studied. In this study, niobium carbide coatings were deposited on cutting punches and screw taps using the TRD technique. Phase formation and micro-hardness of the coatings were studied using X-ray diffraction and Vickers measurements respectively, and the in-service performance of the coated and uncoated tools was studied through field tests conducted at different numbers of cuts. The results show that the coating significantly improves the wear resistance and the cutting performance of the tools, especially at higher numbers of cuts.
\end{abstract}

Keywords: Thermo-reactive deposition/diffusion, TRD, cutting punches, screw taps, niobium carbide.

\section{RESUMEN}

Los componentes de maquinaria y las herramientas sujetas a ambientes agresivos y fuertes condiciones de desgaste necesitan superficies con buenas propiedades mecánicas. El proceso de deposición/difusión termorreactiva (TRD) es uno de los métodos usados para mejorar las propiedades mecánicas de estos componentes y herramientas, principalmente por su bajo costo y buen desempeño de los recubrimientos depositados. Aunque el proceso TRD es ampliamente usado para recubrir moldes, herramientas de extrusión y punzones entre otros, el desempeño en servicio de herramientas de corte recubiertas usando el proceso TRD no ha sido estudiado extensamente. En este estudio se depositaron recubrimientos de carburo de niobio sobre punzones de corte y machos de roscado usando la técnica TRD. La formación de fases y la microdureza de los recubrimientos se estudió usando difracción de rayos X y dureza Vickers

1 Universidad Militar Nueva Granada, Carrera 11 № 101-80. Bogotá, Colombia. E-mail: diana.marulanda@unimilitar.edu.co; beynor.paez@unimilitar.edu.co

2 Grupo Research in Energy and Materials (REM), Facultad de Ingeniería Mecánica, Universidad Antonio Nariño, Calle 22 Sur, 12 D 81. Bogotá, Colombia. E-mail: dmarulanda@uan.edu.co

3 Grupo Ciencia e Ingeniería de Materiales (CIM). Universidad Santo Tomás, Calle 9th, 51-11. Bogotá, Colombia. E.mail: fabiocastillejo@usantotomas.edu.co

4 Departamento de Ingeniería Mecánica y Mecatrónica. Universidad Nacional de Colombia. Calle 45, 26-85. Bogotá, Colombia. E-mail: jjolayaf@unal.edu.co

* Corresponding author. 
respectivamente, y el desempeño en servicio de las herremientas recubiertas y sin recubrimiento se estudió por medio de pruebas de campo realizadas a diferente número de cortes. Los resultados muestran que el recubrimiento mejora significativamente la resistencia al desgaste y el desempeño del corte de las herramientas, especialmente a un número alto de cortes.

Palabras clave: Deposición/difusión termorreactiva, TRD, punzones de corte, machos de roscar, carburo de niobio.

\section{INTRODUCTION}

In components used in manufacturing, a long component life is desired to improve the productivity of the process. For example, in blanking and piercing, the tool life depends on parameters such as punch-die clearance, punch-die corner radius, punch and die material, among others [1,2]. In other processes such as cutting, low wear of the cutting tools is desired to reduce the early life edge failure by chipping $[3,4]$. Improving the efficiency and reducing the cost of replacing these tools without compromising quality remains a major challenge [5]. The time of tool change is still the subject of studies because of its importance in manufacturing processes and also the monitoring of tool wear involves different parameters [6].

In processes such as tapping, some problems can occur, including clogging with chips due to poor cutting performance or poor chip evacuation, and poor cooling or lubricating [7]. In other processes including punching and blanking, the punch wear, deformation and breakage are the major areas of concern [8]. These problems could be addressed using wear-resistance hard protective coatings [9], which can be deposited using different techniques for example physical vapor deposition - PVD [10-12], chemical vapor deposition - CVD [13], laser cladding [14] and cathodic arc evaporation $[3,15]$. The thermo-reactive deposition/diffusion (TRD) process is another method used for improving the mechanical properties of these components and tools, mainly because of its low cost and good performance of the coatings deposited [16]. Although the TRD process is widely used for coating dies, extrusion tools and punches among others, cutting tools such as screw taps have not been studied, even though homogeneous coatings could be obtained on the complicated geometry and relatively large surface of these components [9].

In this study, niobium carbide ( $\mathrm{NbC}$ ) coatings were deposited on cutting punches and screw taps using the TRD technique. The failure of the coated and uncoated tools caused by wear was studied through field tests of blanking and tapping, respectively, conducted at different numbers of cuts. Niobium carbide is still today a forgotten carbide with hidden properties, and the coatings produced have shown to have excellent tribological behavior with enhanced wear resistance [16,17].

\section{EXPERIMENTAL METHODS AND MATERIALS}

The tools used in this work were cylindrical punches manufactured from AISI D2 steel with $27.4 \mathrm{~mm}$ diameter and $53.5 \mathrm{~mm}$ length, and Whitworth screw taps with $12.7 \mathrm{~mm}$ major diameter and $10.4 \mathrm{~mm}$ tapping drill diameter, manufactured from AISI M2 steel. The tools were heated before the TRD treatment at $600{ }^{\circ} \mathrm{C}$ to avoid thermal stress. The niobium carbide coatings on the tools were produced using the TRD technique in a mixture composed of $81 \%$ borax decahydrate, $16 \%$ ferroniobium and $3 \%$ aluminum at $1050{ }^{\circ} \mathrm{C}$ for 4 hours and atmospheric pressure, in a furnace Nabertherm model N61/h. Quenching was performed in oil at room temperature after the TRD process and finally the treated pieces were subjected to tempering at $500{ }^{\circ} \mathrm{C}$ for 30 minutes [18].

The coatings produced were characterized for phase formation and crystallographic orientation using X-ray diffraction (XRD) in an X-Pert Pro Panalytical working with the following settings: $\theta-2 \theta$ varying from $10^{\circ}$ to $120^{\circ}$, monochromatic CuK $\alpha$ radiation $(\lambda=1.5409 \AA), 45 \mathrm{kV}, 40 \mathrm{~mA}$ and a $0.02^{\circ}$ step size. The samples were taken from the cross section of the tools.

The thickness of the coatings produced was measured using a Jeol JSM 6490-LV Scanning Electron Microscopy (SEM) functioning at $10 \mathrm{kV}$. Vickers micro-hardness was measured using an Esseway 
model 600 hardness tester at a load of $100 \mathrm{gf}$ and $20 \mathrm{~s}$ dwell time. The reported values are the average of 4 readings.

The in-service tests for the cutting punches were carried out by blanking operations, in the cutting of AISI 1045 steel sheets with $12 \mathrm{~mm}$ thickness and a speed of 25 strokes per minute. After 100, 200 and 300 cutting cycles the punches were removed from the machine for qualitative wear evaluation. Additional cycles were performed until the punch showed excessive wear or the burr height reached the maximum acceptable level. Pictures of the uncoated and coated punches were taken to compare the performance of the tools.

Tests of the lifetime of the Whitworth screw taps were performed by tapping operations, in the cutting of AISI 1045 steel sheets with $30 \mathrm{~mm}$ thickness and $40 \mathrm{rpm}$ speed. Coolant was used to produce more efficient chip evacuation. The qualitative wear evaluation was performed after 25,35 and 50 threads, and after the complete blunting of the screw taps. The performance of the treatments was evaluated qualitatively through the observation and comparison of the wear in the cutting edges and corners of the tools after the cutting cycles, using a stereomicroscope Nikon model SMZ800 with integrated CCD.

\section{RESULTS AND DISCUSSION}

\section{Microstructure and hardness of the coatings}

Figure 1 shows X-ray diffraction patterns for the coatings produced on the tools used in this study. From these results the presence of niobium carbide (NbC - JCPDS 00-038-1364) is confirmed for the punches and screw-taps. Crystallographic planes are observed in orientations (111), (200) and (311), with crystal cubic system (Fm3m) and space group 225 . As the layers are formed as a consequence of the direct combination of carbon in the steel with niobium dissolved in the bath, the presence of alloying elements in the steel does not have effect on the composition of the coatings [19].

Figure 2 shows SEM micrographs of the crosssection of the coatings produced on the tools. Homogeneous coatings were obtained with $1.9 \pm 0.2$ $\mu \mathrm{m}$ and $13.7 \pm 0.2 \mu \mathrm{m}$ thicknesses for the screw taps and cutting punches respectively. These values are in agreement with the thickness obtained in other works for the same substrates [17]. The difference in the thickness for the two substrates is due to the different carbon contents of the steel, which is 0.9 wt. $\%$ for AISI M2 (screw taps) and $1.51 \mathrm{wt} \%$ for AISI D2 (cutting punches). A clear interface between the coating and the substrate is also observed.

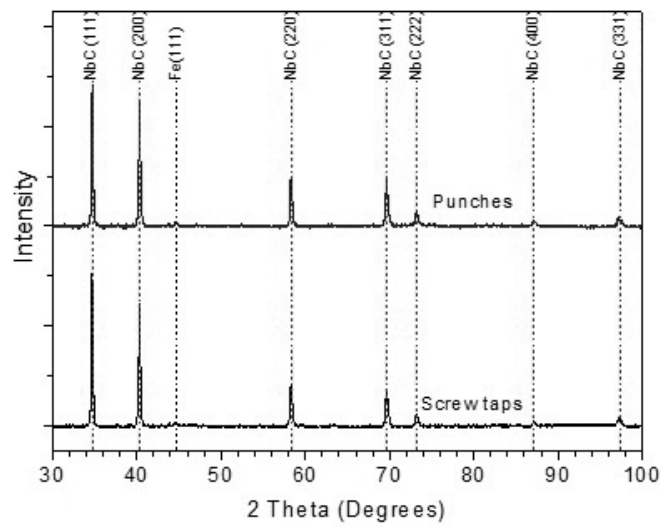

Figure 1. X-Ray diffraction pattern of the coatings produced on the punches and screw taps.

The hardness values measured for the coatings produced were $2390 \pm 90 \mathrm{Hv}$ for the screw taps and $2600 \pm 100 \mathrm{Hv}$ for the cutting punches. These high values are associated to the ceramic condition of the coatings in which ionic bonds are formed reducing dislocation mobility. These values are also in agreement with hardness values reported in other works [17].

\section{Blanking punch test}

A qualitative analysis of the wear in the cutting edges of the punches after blanking operations was done. The lifetime of the punches was judged by the number of holes blanked prior to failure. Figure 3 shows side views of the untreated and treated cutting punches after 100, 300 and 800 strokes. After 100 holes no significant change is observed for the untreated and treated punches. After 300 strokes, the untreated punch shows mild wear but the corners are still sharp, whereas the treated punch is still sharp (Figure $4 \mathrm{a}$ and $\mathrm{b}$ ).

After 800 strokes, tool wear for the untreated punch is more severe, with edge rounding due to wear (Figure 4(c)). Edge rounding increases the tool radius affecting the working capability of the punch [20] 


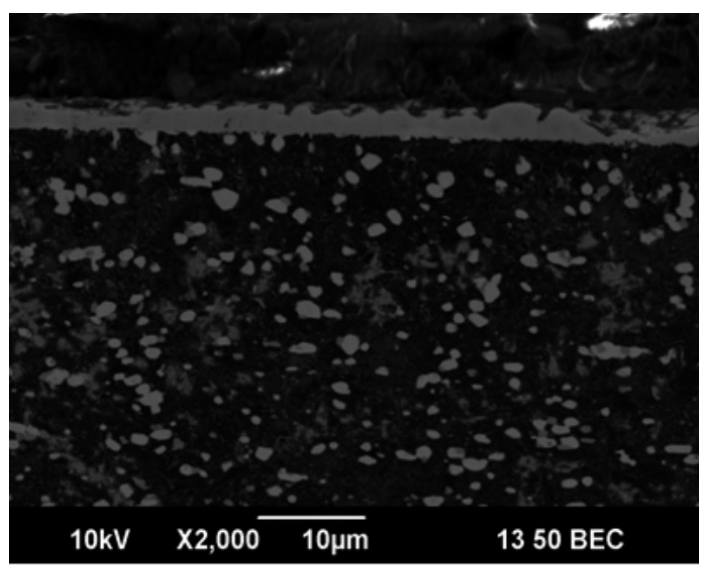

(a)

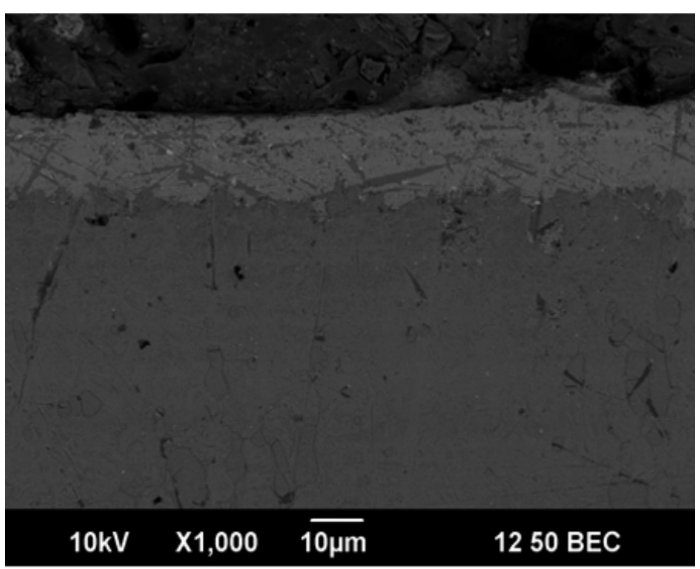

(b)

Figure 2. SEM micrographs for the cross section of the coatings produced on (a) screw taps and (b) cutting punches.

and could produce the formation of burr height in the blanked sheet [21]. Burr length is generally an important criterion in the industry to evaluate part quality [22] and the apparition of burr is the most incapacitating in the use of the blanking piece. Edge chipping is also observed in figure 3, which is caused by the repeated impact loads. The loss of material is not uniform along the cutting edge.

During sheet metal blanking, the work-piece material and the punch are exposed to different stress conditions which cause the cutting edge of the punch to undergo elastic and plastic deformation that affects the working capability of the punch [23]. In addition, after 800 strokes, the increase in heat needed to generate chemical reactions between oxygen in air and the elements in the coating could favor the formation of hard surface oxides, which could result in delamination by corrosive wear. The corrosive wear is accompanied with acceleration of degrading the surface and generally results in more damage due to the wear-corrosion synergy [24]. Another mechanism that could be present is contact fatigue, which appears in machine components that are subjected to cyclic loading, causing micro-cracks, debonding or voids among others, in the areas of stress concentration within the material [25].

On the other hand, adhered material is observed in the uncoated punch, which is typical of wear in blanking of soft steel $[8,26]$. Adhesive wear can occur even at the first stroke and causes strong adhesion between metals due to electron transfer between contacting surfaces, resulting in chemical bonding [27].

For the treated tool, mild wear and small chipping is observed in the face of the tool after 800 strokes (Figure 4d), probably due to the repeated impact loads. However, the edges are still sharp as can be seen in Figure 3. This means that the treated punch has a longer lifetime that the untreated tool. The coating reduces adhesive wear because of the increase in surface hardness and reducing friction, acting as a lubricant, consequently increasing the cutting tool life. The increased tool life can significantly reduce machine downtime, thus also reducing manufacturing costs [28].

\section{Tapping tests}

The lifetime of the screw taps was qualitatively analyzed by tapping tests. Figure 5 shows side views of the uncoated and coated taps after 25 , 35 and 50 threads. The screw-taps were tested up to the failure. After 25 threads there is no visible change in the surface of the screw taps. After 35 threads, the chips of the work-piece can be seen to adhere to the surface of the uncoated screw-tap by mechanical bonding. This is not observed for the treated screw-tap. Chips can damage the threads or cause the tool to break off $[29,30]$. After 50 threads, more tapping chips have been adhered to the untreated tool and also edge chipping is presented. This failure mode is associated to the cutting speed which causes the thermal and mechanical loads to 


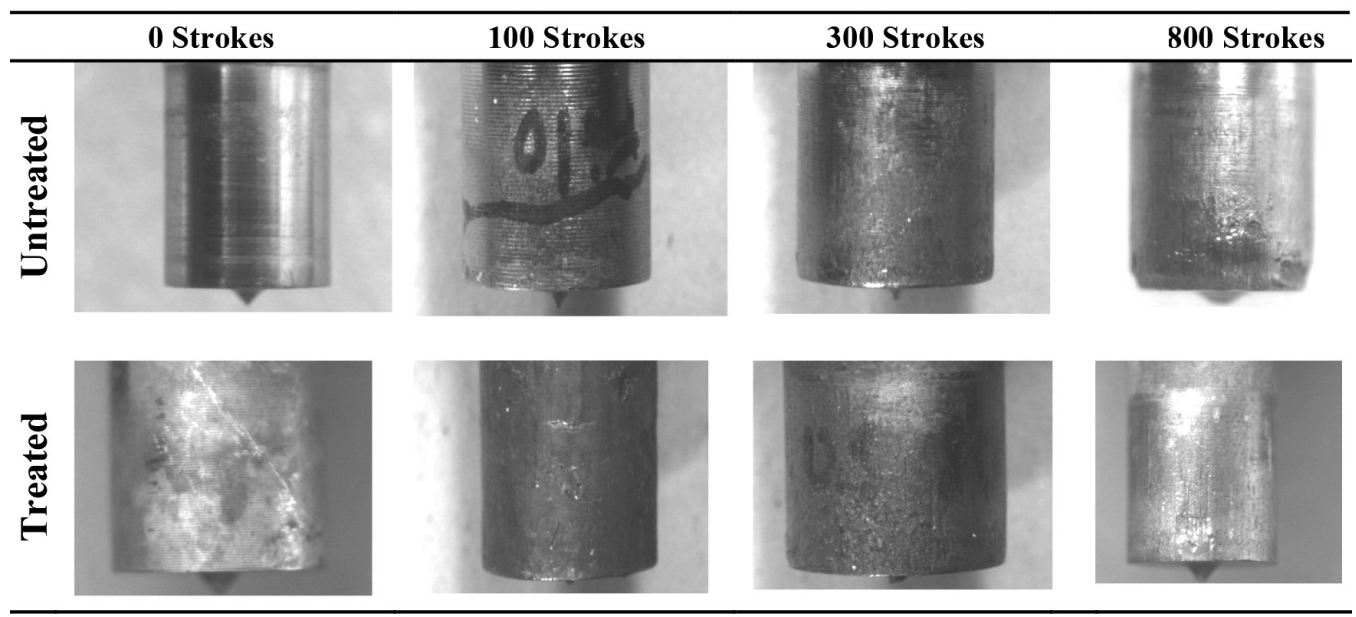

Figure 3. Side views of the tested punches.

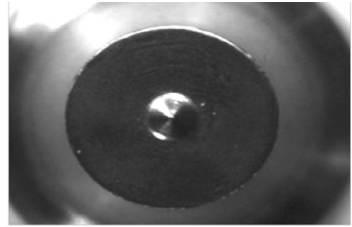

(a)

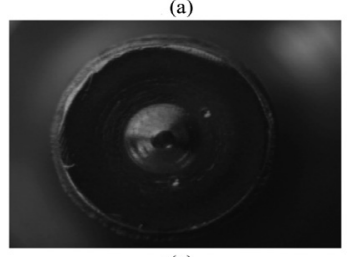

(c)

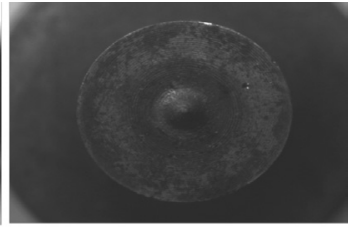

(b)

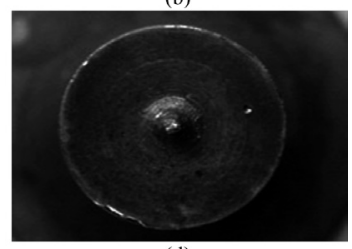

(d)

Figure 4. Front views of the tested punches.

(a) Untreated punch after 300 strokes,

(b) Treated punch after 300 strokes.

(c) Untreated punch after 800 strokes.

(d) Treated punch after 800 strokes.

increase by raising the temperatures in the cutting area, and this speeds up the deformation of the cutting tools [31]. An insufficient cutting fluid can also produce chipping. In addition, the hardness of the untreated tool is lower than hardness of the treated tool and therefore its wear resistance is lower. Tapping is usually the last process in most production procedures and if any problem occurs, the manufacturers could suffer great economic losses due to many bad products [32]. At this point the coated tool has not presented any visible damage or chip adhesion. This would indicate that the $\mathrm{NbC}$ coating reduces the tool/work-piece adhesive interaction.

The uncoated tap failed after 65 threads, where tool break down is presented. The coated tool

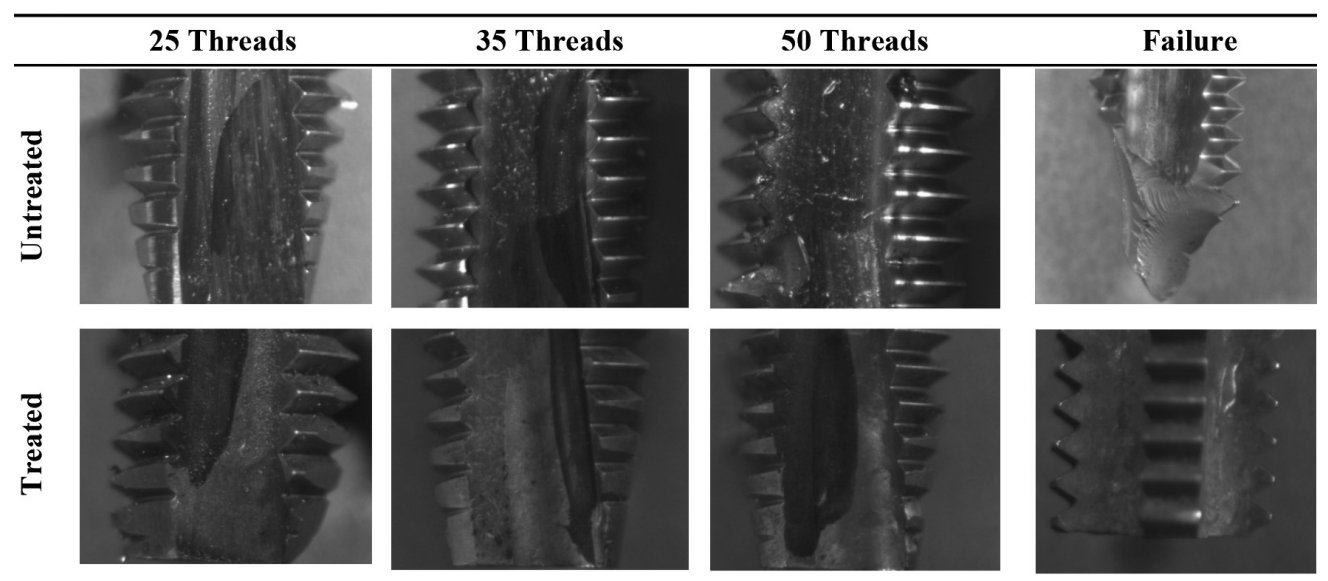

Figure 5. Side views of the screw taps tested. 
was tested up to 110 threads, where a slight wear of the cutting edge is observed. When taps are slightly worn the process is still in control as long as the geometry of the resulting threads of the work-piece is correct [33]. This means that at this point the coated screw tap has not fail and the field tests clearly demonstrate an enhancement in the tapping performance of the coated screw taps in comparison to uncoated tools. In addition, the $\mathrm{NbC}$ layer would act as a lubricant avoiding chip adhesion. Lubrication is of great importance because it influences the wear rate of the cutting tool and the friction between the chip and the tool during the process [34]. The lubrication effect of the $\mathrm{NbC}$ coating could be associated to an excess of carbon atoms on the surface which would be present in the form of graphite of amorphous carbon, where weak secondary Van der Waals forces permits the layers to slide over one another, making it an ideal lubricant [16].

\section{CONCLUSIONS}

In this study, niobium carbide coatings were deposited on cutting punches and screw taps using the TRD technique, and the in-service performance in blanking and tapping operations was studied. The main conclusions are as follows:

(1) The uncoated punches started to fail after 300 strokes, where mild wear was observed. After 800 strokes, the cutting punch failed completely which was associated to adhesion wear, edge chipping and edge rounding. The use of $\mathrm{NbC}$ coated punches prolonged the tool life and generated mild wear at 800 strokes, where the uncoated punch had failed.

(2) For the tapping tests, the NbC coating acted as a lubricant reducing the tool/work-piece adhesive interaction. The coated screw taps showed no enhancement in the tapping performance under testing conditions, whereas the uncoated tools did. The lubrication effect could be associated to an excess of carbon atoms in the $\mathrm{NbC}$ coating.

\section{AKCNOWLEDGMENTS}

The authors gratefully acknowledge the financial support of the Universidad Antonio Nariño, Colombia, in the development of this research project.

\section{REFERENCES}

[1] S. Subramonian, T. Altan, B. Ciorcirlan, C. Campbell. "Optimum Selection of Variable Punch-Die Clearance to Improve Tool Life in Blanking Non-Symmetric Shapes". Int. J. Mach. Tools Manuf. Vol. 75, pp. 63-71. 2013.

[2] M. Murakawa, M. Suzuki, T. Shionome, F. Komuro, A. Harai, A. Matsumoto, N. Koga. "Precision Piercing and Blanking of Ultrahigh-Strength Steel Sheets". Procedia Eng. Vol. 81, pp. 1114-1120. 2014.

[3] A. Pilkington, S.J. Dowey, J.T. Toton, E.D. Doyle. "Machining with AlCr-Oxinitride PVD Coated Cutting Tools". Tribol. Int. Vol. 65, pp. 303-313. 2013.

[4] J. Wang, P. Feng, J. Zhang, C. Zhang, Z. Pei. "Modeling the Dependency of Edge Chipping Size on the Material Properties and Cutting Force for Rotary Ultrasonic Drilling of Brittle Materials". Int. J. Mach. Tools Manuf. Vol. 101, pp. 18-27. 2016.

[5] Y. Wang. "Study on the System Matching of Ultrasonic Vibration Assisted Grinding for Hard and Brittle Materials Processing". Int. J. Mach. Tools Manuf. Vol. 77, pp. 66-73. 2014.

[6] L.H.A. Maia, A.M. Abrao, W.L. Vasconcelos, W.F. Sales, A.R. Machado. "A New Approach for Detection of Wear Mechanisms and Determination of Tool Life in Turning Using Acoustic Emission”. Tribol. Int. Vol. 92, pp. 519-532. 2015.

[7] G. Dinger. "Dynamic Modeling and Simulation of the Screwing Behavior of Thread Forming Screws". J. Manuf. Process. Vol. 20, pp. 374-379. 2015.

[8] R. Shivpuri, S. Singh, K. Agarwal, C. Liu. "Energy Release Rate Based Approach for the Wear of Punches in Precision Blanking of High Strength Steel”. CIRP Anals - Manuf. Technol. Vol. 60, pp. 307-310. 2011.

[9] M. Piska, P. Sliwkova. "Surface Parameters, Tribological Tests and Cutting Performance of Coated HSS Taps". Procedia Eng. Vol. 100, pp. 125-134. 2015.

[10] Beake, BD, Ning, L, Gey, Ch, Veldhuis, SC, Komarov, A, Weaver, A, Khanna, M, Fox-Rabinovich, GS, "Wear Performance of Different PVD Coatings During Hard 
Wet End Milling of H13 Tool Steel". Surf. Coat. Technol., 279 118-125 (2015)

[11] F. Sergejev, P. Peetsalu, A. Sivitski, M. Saarna, E. Adoberg. "Surface Fatigue and Wear of PVD Coated Punches During Fine Blanking Operation”. Eng. Fail. Anal. Vol. 18, pp. 1689-1697. 2011.

[12] A. Taguchi, T. Kitami, S. Akamaru, T. Abe. "Hogomeneous Surface Coatings of Bolts, Nuts and Screws by Barrel-Sputtering Technique”. Surf. Coat. Technol. Vol. 201, pp. 9512-9517. 2007.

[13] G.K. Dosbaeva, M.A. El Hakim, M.A. Shalaby, J.E. Krzanowski, S.C. Veldhuis. "Cutting Temperature Performance on PCBN and CVD Coated Carbide Tools in Hard Turning of D2 Tool Steel". Int. J. Refract. Met. Hard Mat. Vol. 50, pp. 1-8. 2015.

[14] M. Pleterski, T. Muhic, B. Podgornik, J. Tusek, "Blanking Punch Life Improvement by Laser Cladding". Eng. Fail. Anal. Vol. 18, pp. 1527-1537. 2011.

[15] G.B. Both, A.S. Rocha, G.R. Santos, T.K. Hirsch. "An Investigation on the Suitability of Different Surface Treatments Applied to a DIN X100CrMoV8-1-1 for Cold Forming Applications". Surf. Coat. Technol. Vol. 244, pp. 142-150. 2014.

[16] F.E. Castillejo, D.M. Marulanda, J.J. Olaya, J.E. Alfonso. "Wear and Corrosion Resistance of Niobium-Chromium Carbide Coatings on AISI D2 Produced Through TRD”. Surf. Coat. Technol. Vol. 254, pp. 104-111. 2014.

[17] M. Woydt, H. Mohrbacher. "The Use of Niobium Carbide (NbC) as Cutting Tools and for Wear Resistant Tribosystems". Int. J. Refract. Met. Hard Mat. Vol. 49, pp. 212218. 2015.

[18] F. Castillejo, D. Marulanda, O. Rodríguez, J. Olaya. "Electrical Furnace for Producing Carbide Coatings Using the Thermoreactive Deposition/Diffusion Technique". Dyna. Vol. 78, pp. 192-197. 2011.

[19] F.E. Castillejo, D.M. Marulanda, J.J. Olaya. "Production and Characterization of Niobium Carbide Coatings Produced on Tool Steels by Thermorreactive Deposition/Diffusion". Ingeniare. Rev. Chilena Ing. Vol. 22, pp. 189195. 2014.

[20] M. Çöl, D. Kir, E. Erişir. "Wear and Blanking Performance of AlCrN PVD-Coated
Punches”. Mat. Sci. Vol. 48, pp. 514-520. 2013.

[21] E. Falconnet, H. Makich, J. Chambert, G. Monteil, P. Picart, "Numerical and Experimental Analyses of Punch Wear in the Blanking of Copper Alloy Thin Sheet". Wear. Vol. 296, pp. 598-606. 2012.

[22] A. Taylan, T. Erman. "Sheet Metal Forming, Processes and Applications". ASM International, Ohio. 2012.

[23] P. Demmel, H. Hoffmann, R. Golle, C. Intra, W. Volk. "Interaction of Heat Generation and Material Behaviour in Sheet Metal Blanking”. CIRP Anals - Manuf. Technol. Vol. 64, pp. 249-252. 2015.

[24] S.M. Shirazi, F. Akhlaghi, D.Y. Li. "Effect of SiC Content on Dry Sliding Wear, Corrosion and Corrosive Wear of $\mathrm{Al} / \mathrm{SiC}$ Nanocomposites". Trans. Nonferrous Met. Soc. China. Vol. 26, pp. 1801-1808. 2016.

[25] A. A. Walvekar, F. Sadeghi. "Rolling Contact Fatigue of Case Carburized Steels". Int. J. Fatigue Vol. 95, pp. 264-281. 2017.

[26] A. Tshinjan, H. Klaasen, J. Kubarsepp, E. Adoberg, F. Sergejev, A. Talkop. "Wear Performance of PVD Coated Tool Steels". Estonian J. Eng. Vol. 18, pp. 202-210. 2012.

[27] P. Tröber, H.A. Weiss, T. Kopp, R. Golle, W. Volk. "On the Correlation Between Thermoelectricity and Adhesive Tool Wear During Blanking of Aluminum Sheets". Int. J. Mach. Tools Manuf. Vol. 118-119, pp. 91-97. 2017.

[28] L. Wang, X. Nie, J. Housden, E. Spain, J.C. Jiang, E.I. Meletis, A. Leyland, A. Matthews. "Materials Transfer Phenomena and Failure Mechanisms of a Nanostructured Cr-Al-N Coating in Laboratory Wear Tests and an Industrial Punch Tool Application". Surf. Coat. Technol. Vol. 203, pp. 816-821. 2008.

[29] S. Bhowmick, M.J. Lukitsch, A.T. Alpas. "Tapping of Al-Si Alloys with DiamondLike Carbon Coated Tools and Minimum Quantity Lubrication”. J. Mat. Process. Technol. Vol. 210, pp. 2142-2153. 2010.

[30] A. Steininger, A. Siller, F. Bleicher, "Investigations Regarding Process Stability Aspects in Thread Tapping Al-Si Alloys". Procedia Eng. Vol. 100, pp. 1124-1132. 2015.

[31] T. Kivak. "Optimization of Surface Roughness and Flank Wear Using the Taguchi Method 
in Milling of Hadfield Steel With PVD and CVD Coated Steels". Measurement. Vol. 50, pp. 19-28. 2014.

[32] C.W. Yao. "A Study of Contact Interface and Wear Diagnosis for Hand Taps Using Ultrasonic Method". Appl. Acoust. Vol. 85, pp. 46-56. 2014.

[33] A. Gil de Val, J. Fernández, M. Arizmendi, F. Veiga, J.L. Urízar, A. Berriozábal, A. Axpe,
P.M. Diéguez. "On Line Diagnosis Strategy of Thread Quality in Tapping". Procedia Eng. Vol. 63, pp. 208-217. 2013.

[34] S.A. Lawal, I.A. Choudhury, Y. Nukman. "A Critical Assessment of Lubrication Techniques in Machining Processes: A Case for Minimum Quantity Lubrication Using Vegetable Oil-Based Lubricant". J. Cleaner Prod. Vol. 41, pp. 210-221. 2013. 